\title{
CORE CORPORATE GOVERNANCE DILEMMAS FACING BOARDS: A South African Perspective
}

\author{
Hyram Serretta \\ Wits Business School, University of the Witwatersrand \\ Mike Bendixen \\ H Wayne Huizenga School of Business and Entrepreneurship, \\ Nova Southeastern University, Fort Lauderdale \\ Margie Sutherland \\ Gordon Institute of Business Science, University of Pretoria
}

\begin{abstract}
Directors and boards face many challenges in terms of managing complexity. A key factor of success in practising good corporate governance is the board's ability to cope with paradox. The purpose of this research has been to explore the core corporate governance dilemmas facing boards. The investigation was qualitative in nature using the Delphi technique. Six core corporate governance dilemmas facing board members were identified one of which is not mentioned in the international literature. The findings should provide directors with an ability to identify the nature of the paradoxes to which they need to respond.
\end{abstract}

Abstract

JEL L20; M10

\section{1}

\section{Introduction}

Sundaramurthy \& Lewis (2003) highlight that the governance of a modern corporation is an intricate challenge in that it is characterised by competing needs and perspectives, and that it is imperative that these competing needs be embraced in practice and theory. The expectations and tasks of directors within the corporate governance process often lead to the necessity to manage dilemmas; to hold an adequate balance between social goals and economic goals, and between communal and individual goals, and to align the interests of the organisation, society and all stakeholders. Many authors emphasise the need for dilemma management in current times of diversity and change (Berry \& Hülsmann, 2004). Dilemma management originated from Japanese management approaches in the early 1980s, where the ability to cope with paradox was a key factor to success (Berry \& Hülsmann, 2004).
According to Garratt (1996) dilemmas arise due to the complex role of directors, part of which entails dealing with many decisions that are contradictory in nature. Typically, dilemmas are defined as two extreme options, elements or propositions that are opposite to each other and imply conflicting gains. A balance or tradeoff must be achieved between these options, elements or propositions (Minkes, Small \& Chatterjee, 1999; University of Cambridge, 2002; Carter \& Lorsch, 2003; Garratt, 2003 and Hampden-Turner, 2003). Sundaramurthy \& Lewis (2003) believe that it is important that current governance issues be reframed to move beyond either/or thinking thus advocating a balanced perspective. They suggest that research be conducted to understand the dynamic balance among governance imperatives. Carter and Lorsch (2003) assert that unresolved contradictions in board design have never been acknowledged. They draw attention to the fact that such contradictions have not made it onto the radars or agendas of boards. 
The purpose of the research is to identify and rank order the core corporate governance dilemmas facing boards. The results of the research can be drawn on by both executive and non-executive directors to understand the dualities that they are faced with in executing their duties.

\section{2}

\section{Literature review}

Global institutional investors consider board practices as important as financial performance in evaluating companies for potential investment (Sheng, 2003). In support of this point, Hartslief (2003) suggests that sound governance can avoid the unnecessary decline and collapse of a company. Wixley and Everingham (2002) assert that good corporate governance is not a guarantee against failure for organisations but that it ensures adequate disclosure of risks undertaken, and that in the event that businesses run into difficulties, the risks are handled with integrity and wisdom, and that they are handled in the best interests of the enterprise and communicated adequately to shareholders.
The premiums that investors are willing to pay for well-governed companies are greater in emerging markets than they are in developed countries (King Committee on Corporate Governance, 2002). Myburgh (2003) corroborates King's views that South African companies must demonstrate impeccable governance standards in principle and in practice so as to attract emerging market global investors. Tricker (1984) believes the role of corporate governance is that companies need to be regulated in society through conformance so as to avert any abuses of corporate power without restraining flexibility, risk-taking and innovation, and that the quality and activities of boards need to be constantly improved. This requirement informs the substance of the dilemmas at the centre of this article.

Hess (2001) and George (2003) support the notion that governance of a corporation is an intricate challenge and refers mainly to the competing interests of stakeholders that continually confront directors and require concurrent fulfilment through a balanced approach. A list of potential stakeholder groups and their often conflicting concerns are shown in Table 1.

Table 1

Stakeholder groups and their concerns

\begin{tabular}{|l|l|}
\hline \multicolumn{1}{|c|}{ Stakeholder group } & \multicolumn{1}{c|}{ Issues of concern } \\
\hline Customers & $\begin{array}{l}\text { Product safety and content; } \\
\text { Advertising practices; } \\
\text { Trade-off between product/service price and } \\
\text { environmental and social issues. }\end{array}$ \\
\hline Community & $\begin{array}{l}\text { Charitable contributions; } \\
\text { Local employment; } \\
\text { Impact on environment; } \\
\text { Political activity and regulatory compliance. }\end{array}$ \\
\hline Employees & $\begin{array}{l}\text { Wages and benefits; } \\
\text { Health and safety; } \\
\text { Training and advancement; } \\
\text { Gender issues. }\end{array}$ \\
\hline Environment & $\begin{array}{l}\text { Regulatory compliance; } \\
\text { Emissions and hazardous materials; } \\
\text { Waste reduction and recycling programs; } \\
\text { Environmentally friendly packaging. }\end{array}$ \\
\hline Institutional Investors & $\begin{array}{l}\text { Financial returns; } \\
\text { Good corporate governance. }\end{array}$ \\
\hline
\end{tabular}




\begin{tabular}{|l|l|}
\hline Shareholders (majority and minority shareholders) & Financial returns; \\
& $\begin{array}{l}\text { Accurate and timely disclosure of operations and } \\
\text { performance; } \\
\text { Corporate governance, including executive } \\
\text { compensation; } \\
\text { Shareholder proxies. }\end{array}$ \\
\hline Suppliers & $\begin{array}{l}\text { Social and environmental performance; } \\
\text { Standards for selecting and monitoring suppliers. }\end{array}$ \\
\hline
\end{tabular}

Source: Adapted from Hess (2001:318) and Coyle (2003:9)

\section{Corporate governance dilemmas}

The London Institute of Directors (1995) describes the four roles of the board, which Garratt (1996, 2003) refers to as the four "Directorial Dilemmas" of corporate governance. The four roles appear to be dilemmas, as they seem to be contradictions in themselves and they require an adequate balance between apparently conflicting goals. They also require alignment to the interests of the organisation, society and all stakeholders.

\section{Corporate governance dilemma one}

The first dilemma is that the board must drive the business forward in an entrepreneurial manner whilst ensuring prudent control. This means that the board is tasked with holding a balance between performance and conformance (Garratt, 1996). The substance of this dilemma lies in the board's legal fiduciary duty to hold the company in trust on behalf of the shareholders whilst being entrepreneurial to maximise shareholder value.

The King Committee on Corporate Governance (2002) suggests that the role and function of the board encapsulates this challenge as a principal requirement, while Garratt (2003) suggests that sustaining this dynamic and changing balance constitutes the essence of effective corporate governance.

Sharman and Copnell (2003) believe that good corporate governance has real value in its contribution to both business prosperity and to accountability. Tricker (1984) states that the role of control and conformance concerns the regulation of companies in society, thus preventing abuse of power. Another factor that has played a significant role in driving the need for conformance, according to Coyle (2003), is the recent spate of corporate failures.
According to Zahra (1996), corporate entrepreneurship is concerned with radical product innovation, risk taking, proactiveness, business venturing and "intrapreneuring". Zahra, Neubaum and Huse (2000) state that corporate entrepreneurship helps companies to enter new businesses, develop new revenue streams and improve profitability and growth. To illustrate the relationship between performance and corporate entrepreneurship, Zahra et al. (2000) posit that corporate entrepreneurship is positively associated with the future performance of a company. Sharman and Copnell (2003) also believe that there is a positive relationship between greater risk-taking and shareholder value.

Sundaramurthy and Lewis (2003) consider the tensions that emanate from the coexistence of control and collaboration, some of which could affect performance negatively by creating management behaviour that stifles growth and fruition in a company. They contend that excessive control by outsiders on the board that do not understand internal operations leads to the formulation and use of financial controls rather than subjective strategic controls. Zahra et al. (2000) suggest that an exclusive use of financial criteria will lead to a decline in entrepreneurial activity and that managers will be less willing to take risks. Conformance to new accounting standards such as GAAP (Generally Accepted Accounting Principles) and IFRS (International Financial Reporting Standards) has the potential to affect the financial success of an organisation negatively through unfair presentation, obscuring an accurate view of financial status and through concealing risk by means of conservatism (King, 1992; Cox, 2003 and Livne \& McNichols, 2004). 
Why the dilemma might not be a dilemma: An opposing argument can be presented to that of the suggested negative effects of conformance on performance or of the negative effects of control on entrepreneurial activity in firms. The central principle of this argument is that control can be exercised in a manner that earns improved profitability and returns to shareholders in the long run. The basis of this particular argument is that a balance is not the central tenet in managing this dilemma but that there exists a positive causal relationship between control and performance. It suggests that directors' commitment to corporate entrepreneurship and performance can be shaped by the mechanisms of control and conformance, which constitute part of the larger system of corporate governance (Zahra, 1996). $\mathrm{He}$ also posits that strong vigilant directors have the capacity to encourage managers to pursue corporate entrepreneurial activities.

\section{Corporate governance dilemma two}

The second dilemma is that the board must possess sufficient knowledge of the day-to-day workings of the organisation to be responsible for its actions whilst being able to find time to develop a longer-term objective "helicopter" view of the business and developments outside (Garratt, 2003). The first proposition of this dilemma encompasses the roles of supervisory management (short-term, internally oriented thinking and organisational efficiency), accountability and responsibility while the second proposition of the dilemma encompasses an objective view of the business (long-term, externally oriented thinking and organisational effectiveness) (Garratt, 1996).

Sundaramurthy and Lewis (2003:397) succinctly express one of the drivers of this dilemma by stating, "Board members are expected to provide critical judgement on management performance - which requires an in-depth knowledge of, and intimacy with the affairs of the corporation - and at the same time to assure that this judgement is independent." Directors are compelled to know the detailed workings of their companies so that they can also fulfil their responsibilities and liabilities set out by the law, and so that they can address the mass of corporate and industry governance codes. Director-oriented laws and corporate governance codes are growing rapidly. There are, for example, at least four hundred laws in the UK defining directors' responsibilities and liabilities (Garratt, 1996). Scherrer (2003) suggests that boards need to be sufficiently aware of the workings of their companies so that they can provide accurate information to their shareholders and detect and understand signals of distress. This will allow directors to address managerial issues in a timely manner.

There are four aspects to developing a longterm objective view of developments outside of the organisation that set a context that takes broad trends and international competition into consideration (Garratt, 2003). The four aspects are: purpose; vision and values, emotional climate and culture; and monitoring the external environment. The other significant driver is the need for the board to position the organisation in all political environments comprising party political aspects, national and regional political aspects, environmental and economic aspects, and social, technological and trade aspects (Garratt, 1996). Scherrer (2003) suggests that in order to understand and detect business failure, the board must understand the effects of external business environments on business stability and profitability. He also believes that the external environment is uncontrollable and complex, and therefore directors prefer to consider short-term internal changes and workings.

Why the dilemma might not be a dilemma: Carter and Lorsch (2003) suggest that directors, who do not know enough of the daily workings of the business, do not understand and are not able to approve strategic moves and are not able to judge performance. In order to decide about a company's future, boards need to be able to understand the workings of the organisation that drive strategic success, and they need to understand the major issues facing a company. A long-term objective view of developments external to the organisation also encompasses the company's future, which therefore requires a fulfilment of the requirement to understand the organisation in detail as suggested by Carter and Lorsch. A lack of understanding of all these elements and their interactions fosters behaviour 
that ignores the signals of failure. The fact that directors are more reliant on management is diametrically opposite to what independence is intended to achieve (Carter \& Lorsch, 2003).

\section{Corporate governance dilemma three}

The third dilemma is that the board must be mindful of short-term local demands whilst being able to balance these against broader regional, national and international trends and competition (Garratt, 2003). Percy (1995) endorses this view by stating that the direction and strategy of a company in the long-term can be at conflict with the daily short-term management of the company. This view entails a balancing of organisational efficiency with organisational effectiveness, in the form of the short-term internal supervision of management and long-term strategic thinking, respectively. Strategic thinking also entails how policies will be implemented in the long term by considering broad trends and competition nationally and internationally (Garratt, 1996).

Percy (1995) believes that a common thread of business failure was the lack of operational and internal control within companies. He reminds us that it is the director's duty to report on the system of internal control of the company, a system that is short-term oriented. Spira (2001) and Taylor (2003) suggest that it is the board's role to maintain a sound system of internal and financial control in order to safeguard the shareholder's investment and the company's assets. In order to cover all controls, operations and risk, the board needs to attend to the short-term demands of the business. Cornell (2003) posits that in order to fulfil one of the fundamental duties of helping management to maximise shareholder value, boards should understand how a company creates value. Being sensitive to the short-term demands of the business can achieve this.

A driver of sensitivity to short-term demand is the requirement to meet short-run earnings targets (Graham, Harvey \& Rajgopal, 2004). This demand is driven internally by management and externally by investors. Coyle (2003) suggests that directors should consider the long term and not just the short term as they should consider the interests of all stakeholders and not just shareholders who also desire good shortterm returns. Shareholders impose rigorous financial controls, which drive short-termism (Taylor, 2003). The need for long-term strategic thinking is driven by the need to maximise long-term organisational effectiveness on the part of the board (Garratt, 2003). Wixley and Everingham (2002) echo the view endorsed by the King Committee on Corporate Governance (2002), that strategy formulation and execution are the most important responsibilities of directors. Strategic thinking is continuous longterm internally oriented thinking, and matching this internal view with broader regional, national and international trends for the long-term sustainability of the business (Garratt, 1996). It is Garratt's (1996) view that strategy entails consultation with parties within and without the organisation and that the responsibility lies firmly with the board of directors. The board has to consider long-term trends outside the business by examining feedback from customers, competitor intelligence systems, national and international legislation, local and wider communities and international economic, political and trade environments (Garratt, 1996).

Dimma (1995) proposes that the best boards of the most successful companies think strategically as a matter of course, and that strategic thinking improves performance and long-run profitability. An excessive focus on strategic thinking, and a lack of concentration on aspects of supervisory management like risk management and control, could force an outcome where supervision of management is not addressed carefully and becomes a black hole into which all the energies of the board are drawn (Garratt, 1996). A great deal of available evidence suggests that boards that ensure that companies are run with a long-term view of the interests of key stakeholders, are more likely to prosper than those with short-term 'shareholder first' perspectives (Sillanpää, 1998). Short-termism results in an excessive orientation towards short-term profits, at the expense of long-term research and development (R\&D) activities (Cescon, 2002). An overemphasis on short-term demands reduces the tendency of the board to consider changes in the broader external environment. 
Why the dilemma might not be a dilemma; Spira (2001) holds the view that the focus on some short-term demands goes hand-in-hand with the focus on strategy and that meeting a particular short-term demand addresses the need to think strategically. He suggests that the short-term demands related to risk control emphasise the links to strategy formulation and support the enterprise strategy.

\section{Corporate governance dilemma four}

The fourth dilemma is that the board is required to focus on the commercial needs of the business whilst operating responsibly and ethically towards all shareholders and stakeholders (Garratt, 1996). Hess (2001) suggests that a model of regulation is required that makes corporations responsive to the ever-changing societal expectations of proper corporate behaviour.

A reason for the existence of this dilemma is the requirement of a good and inclusive approach to corporate governance (King Committee on Corporate Governance, 2002). This requirement concerns holding an adequate balance between social goals and economic goals. Directors face a dilemma in this regard as they may believe their role is to generate profits for majority shareholders at all costs, thus ignoring their obligations of accountability to key stakeholders like employees, customers, suppliers, minority shareholders, subsidiary companies and society. Freeman and Harrison (1999) argue that companies are obligated to provide substantial returns to shareholders but in so doing, their strategies in this regard lead to actions that various stakeholders find offensive. These obligations to a wide range of stakeholders cannot be ignored, and must be a primary concern in terms of good corporate governance, as stakeholders seek and demand information on a corporation's social performance.

The existence and pertinence of this dilemma is further corroborated by Smith (2003) as he suggests that there is a great deal of uncertainty about the nature and scope of the obligations relating to corporate social responsibility (CSR), further complicating the need to hold an adequate balance between social and economic needs. This dilemma is particularly applicable to the business environments in developing countries like South Africa, where there are pressures for companies to deliver wider societal value. These circumstances include (Freeman \& Harrison, 1999; Hess, 2001; African Institute of Corporate Citizenship, 2002; Hampden-Turner, 2003 and Smith, 2003): high levels of poverty; requirements for equal employment opportunity; concerns for health and occupational safety especially due to the proliferation of HIV/AIDS in companies in developing countries like South Africa; the demands for social justice and economic development; growing environmental concerns; concerns for human rights issues for multi-nationals; the mistrust of big businesses; and heightened societal expectations.

Freeman and Harrison (1999) in research on the relationship between socially responsible organisational behaviour and various types of performance, contend that economic effects are social and that social effects are economic. However, Smith (2003) posits that an increased focus on social performance dilutes director focus on profitability and the commercial needs of the company. CSR embraces the "triple bottom line" in the context of corporate governance, whereby companies pay attention to environmental and social impacts in addition to reporting on economic performance (Keay, 2002). This form of reporting introduces further costs in the form of systems to ensure timely availability relevant to environmental costs and liabilities, and systems to support financial and environmental planning and decision-making (KPMG, 2001). A critical consideration for companies that do not contribute adequately to social responsibilities is reputational risk and safeguarding of the brand image (Smith, 2003). The central tenet of this particular argument is that it is difficult to hold a balance between the economic needs and social needs of an organisation simultaneously, as trade-offs among them are required (Hampden-Turner, 2003). The task of managing this dilemma is made more complex by the lack of concrete measures for social performance.

Why the dilemma might not be a dilemma: A contradicting argument can be presented to that of the negative effects of a company's responsibility to its employees, business partners 
and society on the commercial needs of the business and on returns to shareholders. The central tenet of this argument is that these social responsibilities lead to improved profitability and returns to shareholders in the long run. The basis of this argument is that a balance is not the central tenet in managing this dilemma, but that there exists a positive causal relationship between social responsibility and the commercial needs of the business. It suggests that directors are compelled to focus on CSR and cannot afford to ignore it if they are intent on providing shareholders with greater returns.

\section{Conclusion}

The literature review has highlighted the importance of coping with paradox and dilemmas as a capability for success in practising good governance in an increasingly complex marketplace. There is little literature describing empirically the corporate governance dilemmas facing boards of directors. This is the first step needed before the paradoxes can be managed.

\section{3}

\section{Research questions}

The empirical part of this study sought to understand: What are the core corporate governance dilemmas facing boards? What is the relative importance of the dilemmas?

\section{4}

\section{Research methodology}

The primary method of research employed in this study was a qualitative analysis of data collected through a Delphi study. The aim of this study, following Miles and Huberman (1994) in their description of recurring features of qualitative research, is to gain a systemic overview of the context under study, i.e. the origins of corporate governance dilemmas facing boards.

\subsection{Method}

The Delphi technique concerns the use of an experienced group or panel of experts who contribute knowledge, authority and insight (Story, Hurdley, Smith \& Saker, 2001). The
Delphi technique comprises a number of rounds of data collection (Story et al., 2001 and Loo, 2002). The first round is relatively unstructured so that experts can identify and elaborate on applicable issues from their points of view. The researcher then consolidates the issues into a structured questionnaire (Story et al., 2001). The questionnaire is then used to extract the judgements of the panel of experts quantitatively. These are then analysed and summarised statistically and can be presented back to the panel for further consideration (Story et al., 2001 and Loo, 2002). The panel may alter estimates based on the feedback (Erffmeyer et al., 1986). The iteration, feedback and aggregation of group responses serve to produce the highest possible number of quality responses and opinions on the relevant issue(s) from the expert panel so as to enhance decisionmaking (Story et al., 2001). The intended result is a reliable consensus or convergence of opinion (Erffmeyer et al., 1986).

\subsection{Population and sample}

The population from which this sample was selected consisted of all executive and nonexecutive directors, chief executive officers (CEOs) and non-executive chairmen, consultants and academics in South Africa who possess the knowledge and experience necessary to participate in a Delphi study concerning the practices of corporate governance. The sample selection was based on purposeful sampling. "The process of selecting experts is critical to the Delphi and serves to authorise the Delphi's superiority and validity over other less painstaking and rigorous survey procedures" (Clayton, 1997:377). A heterogeneous population was selected to ensure a spectrum of views was represented (Loo, 2002). The researcher acquired the necessary information to target appropriate members of the sample through referrals, business publications and websites and by approaching well-known business leaders in South Africa. Martino (cited in Loo, 2002) suggests the rule of thumb is that 15 to 30 carefully selected experts could be used for a heterogeneous population. The researcher compensated for expected attrition throughout 
the Delphi process by selecting 22 experts, all well known business leaders, to be used on the starting panel. The sample is presented in the following table.

Table 2

Sample profile

\begin{tabular}{|l|c|}
\hline \multicolumn{1}{|c|}{ Title of sample members } & Number of members \\
\hline Non-executive directors & 2 \\
\hline Executive directors & 4 \\
\hline Chief executive officers & 5 \\
\hline Non-executive chairmen & 2 \\
\hline Corporate governance experts/academics & 5 \\
\hline Corporate governance consultants & 4 \\
\hline TOTAL & 22 \\
\hline
\end{tabular}

\subsection{Data collection}

The researcher collected data by means of selfadministered questionnaires for each of the three rounds of the Delphi study. Guarantees were given to respondents that their responses would be kept confidential and that they would remain anonymous in terms of specific responses. The Delphi process as applied in this study is summarised in Table 3.

Table 3

The Delphi process

\begin{tabular}{|l|l|c|}
\hline \multirow{2}{*}{$\begin{array}{l}\text { Round } \\
\text { One }\end{array}$} & $\begin{array}{l}\text { An open-ended question was used to encourage participants to elaborate on the pertinent } \\
\text { problems and opportunities facing boards. This was followed by two structured questions } \\
\text { to encourage the identification of and elaboration on dilemmas and in terms of their own } \\
\text { expert opinion. A short explanation of a dilemma was included. The questionnaire was } \\
\text { returned to the researcher to summarise against the literature. Dilemmas identified by the } \\
\text { respondents and dilemmas not mentioned by the experts but identified in the literature } \\
\text { were summarised and included in the list for the second round. }\end{array}$ & $\begin{array}{c}\text { Nospeces } \\
\text { received }\end{array}$ \\
\hline $\begin{array}{l}\text { Round } \\
\text { Two }\end{array}$ & $\begin{array}{l}\text { The panellists received the summarised list of thirteen dilemmas generated from the } \\
\text { first round in the form of a structured questionnaire and were asked to reconsider } \\
\text { the appropriateness of each core corporate governance dilemma. The experts were } \\
\text { requested to provide reasons why they might disagree with the dilemmas provided } \\
\text { and were given the opportunity to alter their original opinions. If experts provided } \\
\text { additional dilemmas, they were asked to provide an explanation of why they thought } \\
\text { this was a dilemma. The researcher then summarised the responses for the structured } \\
\text { questionnaire in round three. }\end{array}$ & 18 \\
\hline $\begin{array}{l}\text { Round } \\
\text { Three }\end{array}$ & $\begin{array}{l}\text { The panel of experts received the summarised list in the form of a structured } \\
\text { questionnaire to rate the six core dilemmas generated in round two on an importance } \\
\text { scale of 1 to 10, where 1 is of little concern and 10 is most prominent and to elicit } \\
\text { possible best practice suggestions to cope with these dilemmas. The rated corporate } \\
\text { governance dilemmas were then analysed and statistically summarised. The results of } \\
\text { the study were elicited from a final list created after this round. }\end{array}$ & 17 \\
\hline
\end{tabular}




\section{5}

\section{Results}

Content analysis was carried out on responses of the first and second rounds of the Delphi study. This analyses the qualitative written data in an objective, systematic way in order to identify and quantify recurring patterns and themes in the data (Zikmund, 2003). The process exposed 13 core corporate governance dilemmas facing boards. They are presented in Table 4 together with frequency of occurrence and as a percentage of the total incidence of all dilemmas. No additional dilemmas were captured in the second round of the study.

Table 4

List of core corporate governance dilemmas identified - round one

\begin{tabular}{|c|c|c|c|c|c|}
\hline \multirow[b]{2}{*}{ \# } & \multirow[b]{2}{*}{ Dilemma } & \multicolumn{2}{|c|}{ ROUND 1} & \multicolumn{2}{|c|}{ ROUND 2} \\
\hline & & Frequency & $\%$ & Votes for & $\begin{array}{c}\text { Votes } \\
\text { against }\end{array}$ \\
\hline 1 & $\begin{array}{l}\text { The board is tasked with holding a balance between } \\
\text { performance (enterprise and financial success) and } \\
\text { conformance (prudent control). As an example, this } \\
\text { includes circumventing potential misrepresentation } \\
\text { of results due to new rules-based standards whilst } \\
\text { complying. }\end{array}$ & 15 & 23 & 15 & 3 \\
\hline 2 & $\begin{array}{l}\text { The board is tasked with holding a balance between } \\
\text { attractive remuneration for directors to acquire and } \\
\text { retain talent and prudent cost control. }\end{array}$ & 3 & 5 & 13 & 5 \\
\hline 3 & $\begin{array}{l}\text { The board is tasked with holding a balance between } \\
\text { addressing social charter and BEE priorities and being } \\
\text { focused on the commercial needs of the business. }\end{array}$ & 7 & 11 & 17 & 1 \\
\hline 4 & $\begin{array}{l}\text { The board must be mindful of short-term local demands } \\
\text { (e.g. risk management, control, and overseeing } \\
\text { performance) whilst being able to balance these against } \\
\text { broader long-term, national and international trends and } \\
\text { competition (strategic thinking). }\end{array}$ & 7 & 11 & 16 & 2 \\
\hline 5 & $\begin{array}{l}\text { The board must possess sufficient knowledge of the } \\
\text { day-to-day workings of the business to be responsible } \\
\text { for its actions whilst being able to find time to develop } \\
\text { a longer-term objective/independent "helicopter" view } \\
\text { of the business and developments outside (policy } \\
\text { formulation). }\end{array}$ & 5 & 8 & 15 & 3 \\
\hline 6 & $\begin{array}{l}\text { The board is required to focus on the commercial needs } \\
\text { of business whilst operating responsibly and ethically to } \\
\text { all shareholders and stakeholders. }\end{array}$ & 10 & 15 & 12 & 6 \\
\hline 7 & $\begin{array}{l}\text { The board must hold a balance between high risk and } \\
\text { high reward and more certain, consistent performance } \\
\text { and earnings growth. }\end{array}$ & 6 & 9 & 13 & 5 \\
\hline 8 & $\begin{array}{l}\text { The board is tasked with holding a balance between } \\
\text { seizing major growth opportunities in emerging markets } \\
\text { and protecting profitable existing business. }\end{array}$ & 2 & 3 & 14 & 4 \\
\hline
\end{tabular}




\begin{tabular}{|c|c|c|c|c|c|}
\hline \# & Dilemma & Frequency & $\%$ & Votes for & $\begin{array}{c}\text { Votes } \\
\text { against }\end{array}$ \\
\hline 9 & $\begin{array}{l}\text { The board is tasked with holding a balance between } \\
\text { addressing the skills shortage and actively training future } \\
\text { board members for the long-term (expensive) and } \\
\text { hiring skilled people who have received their training } \\
\text { elsewhere. }\end{array}$ & 3 & 5 & 9 & 9 \\
\hline 10 & $\begin{array}{l}\text { The board is tasked with holding a balance } \\
\text { between addressing board succession for diversity, } \\
\text { complimentary skills and independence and keeping the } \\
\text { current set of very competent and successful directors. }\end{array}$ & 4 & 6 & 13 & 5 \\
\hline 11 & $\begin{array}{l}\text { The board must hold a balance between incurring } \\
\text { shareholder activism as a result of lower profit levels } \\
\text { and incurring increased wage demands, calls for price } \\
\text { reductions and complacency as a result of exceptionally } \\
\text { high profit levels. }\end{array}$ & 1 & 2 & 11 & 7 \\
\hline 12 & $\begin{array}{l}\text { Boards of multi-nationals must hold a balance between } \\
\text { setting executive remuneration at international levels } \\
\text { to retain talent and keeping executive remuneration at } \\
\text { national levels to satisfy the media and investors. }\end{array}$ & 1 & 2 & 13 & 5 \\
\hline 13 & $\begin{array}{l}\text { The board must hold a balance between providing } \\
\text { careers for previously disadvantaged employees } \\
\text { (employment equity) and established competence. }\end{array}$ & 2 & 3 & 16 & 2 \\
\hline
\end{tabular}

All dilemmas were considered valid based on the fact that they fit the criteria for a dilemma outlined in the literature review. These dilemmas were therefore included in the second round of the Delphi study. The importance of a dilemma to the panel was established by contending that the dilemma would only be included in the third round of the Delphi study if the dilemma appeared with a consistency of more than fifty percent in the second round. Table 4 illustrates that this is not the case for dilemma nine which has nine votes for and nine votes against and hence this dilemma was excluded in the next round.
The above results were once again considered for reasonableness against the literature and expert convergence around the core corporate governance dilemmas. The outcome of this process was a consolidation of the findings, of round one and round two, into six core corporate governance dilemmas facing boards. The consolidation is discussed in detail in the following section. These six dilemmas were included in the third and final round of the Delphi study and the results are illustrated in Table 5.

\section{Table 5}

Final list of core corporate governance dilemmas facing boards

\begin{tabular}{|c|l|c|}
\hline$\#$ & \multicolumn{1}{c|}{ Dilemma } & Median \\
\hline 1 & $\begin{array}{l}\text { The board is tasked with holding a balance between performance } \\
\text { (entrepreneurship, risk-taking and financial success) and conformance (prudent } \\
\text { control). }\end{array}$ & 8 \\
\hline 2 & $\begin{array}{l}\text { The board must possess sufficient knowledge of the day-to-day workings of the } \\
\text { business to be responsible for its actions whilst being able to find time to develop } \\
\text { a longer-term objective/independent "helicopter" view of the business and } \\
\text { developments outside (policy formulation). }\end{array}$ & 6 \\
\hline
\end{tabular}




\begin{tabular}{|c|l|l|}
\hline 3 & $\begin{array}{l}\text { The board must be mindful of short-term local demands (e.g. risk management, } \\
\text { control, and overseeing performance) whilst being able to balance these against } \\
\text { broader long-term, national and international trends and competition (strategic } \\
\text { thinking). }\end{array}$ & 7 \\
\hline 4 & $\begin{array}{l}\text { The board is required to focus on the commercial needs of business whilst } \\
\text { operating responsibly to all stakeholders in society (customers, suppliers and } \\
\text { society) and in the business (employees and business partners). }\end{array}$ & 6 \\
\hline 5 & $\begin{array}{l}\text { The board is tasked with holding a balance between addressing board succession } \\
\text { for diversity, complimentary skills and independence and keeping the current set } \\
\text { of very competent and successful directors for continuity. }\end{array}$ & \\
\hline 6 & $\begin{array}{l}\text { The board must hold a balance between incurring shareholder activism and } \\
\text { failure to source further funding as a result of lower profit levels and incurring } \\
\text { increased wage demands, calls for price reductions and complacency as a result of } \\
\text { exceptionally high profit levels. }\end{array}$ & \\
\hline
\end{tabular}

A comparison of the six core corporate governance dilemmas and those gleaned from the literature review indicates that four of the dilemmas generated in the study provide support for the dilemmas developed in the literature review. Two additional dilemmas, dilemmas five and six in Table 5, were identified in the current study. The following section justifies and explains the consolidation of the 12 dilemmas into the final six core corporate governance dilemmas and verifies the findings of this study by relating them to the literature.

\section{Core corporate governance dilemma one}

The first core corporate governance dilemma generated in the study was:
The board is tasked with holding a balance between performance (entrepreneurship, risktaking and financial success) and conformance (prudent control). The literature provides mention of the balance required between conformance and performance to ultimately drive shareholder value (Garratt, 1996; King Committee on Corporate Governance, 2002 and Sharman \& Copnell, 2003). The findings affirm the negative impact of over-regulation on performance by mentioning the costs of compliance in terms of money and time. On this basis, four of the 12 dilemmas identified were consolidated into this core corporate governance dilemma. These four dilemmas are displayed in Table 6 below.

\section{Table 6}

Manifestations of core corporate governance dilemma one

\begin{tabular}{|l|l|}
\hline Performance & Conformance \\
\hline $\begin{array}{l}\text { Being focused on the commercial needs of the } \\
\text { business. }\end{array}$ & $\begin{array}{l}\text { Addressing social charter and BEE priorities in the form } \\
\text { of government regulation. }\end{array}$ \\
\hline High risk and high reward. & $\begin{array}{l}\text { More certain, consistent performance and earnings } \\
\text { growth. }\end{array}$ \\
\hline $\begin{array}{l}\text { Seizing major growth opportunities in emerging } \\
\text { markets. }\end{array}$ & Protecting profitable existing business. \\
\hline Keeping established competence. & $\begin{array}{l}\text { Providing careers for previously disadvantaged } \\
\text { employees (employment equity regulations). }\end{array}$ \\
\hline
\end{tabular}




\section{Core corporate governance dilemma two}

The second core corporate governance dilemma generated in the study was: The board must possess sufficient knowledge of the day-to-day workings of the business to be responsible for its actions whilst being able to find time to develop a longer-term objective/independent "helicopter" view of the business and developments outside (policy formulation). The literature provides mention of the balance required between sufficient knowledge of the daily workings of the organisation and possessing the capacity, capabilities and time to hold an objective long- term view of the business (Garratt, 1996 and King Committee on Corporate Governance, 2002). An overload of detailed operational data results in the consumption of valuable time required for developing a strategic external view of the business. The findings in this regard point to the negative impact of one side of the dilemma (detailed knowledge of the business) on the opposing side of the dilemma (independent view), which confirm the dynamics of the dilemma as conveyed in the literature. Manifestations of the second core corporate governance dilemma are presented in Table 7.

\section{Table 7}

Manifestations of core corporate governance dilemma two

\begin{tabular}{|l|l|}
\hline \multicolumn{1}{|c|}{ Sufficient knowledge of day-to-day workings } & \multicolumn{1}{c|}{ Long-term independent/objective helicopter view } \\
\hline $\begin{array}{l}\text { Having sufficient time to build knowledge through an } \\
\text { "inward-looking" perspective. }\end{array}$ & $\begin{array}{l}\text { Having sufficient time to build knowledge through an } \\
\text { "outward-looking" perspective. }\end{array}$ \\
\hline $\begin{array}{l}\text { Having in-depth knowledge of and intimacy with the } \\
\text { affairs of the corporation for accountability. }\end{array}$ & Being independent. \\
\hline $\begin{array}{l}\text { The need to know the detailed workings of the } \\
\text { company. }\end{array}$ & $\begin{array}{l}\text { The need to be aware of the socio-emotional aspects } \\
\text { of the company (purpose, vision, values, emotional } \\
\text { climate and culture) to set corporate policy and } \\
\text { to position the company in all applicable political } \\
\text { environments (including social, economic and trade } \\
\text { aspects). }\end{array}$ \\
\hline
\end{tabular}

\section{Core corporate governance dilemma three}

The third core corporate governance dilemma developed by the study was:

The board must be mindful of short-term local demands (e.g. risk management, control, and overseeing performance) whilst being able to balance these against broader long-term, national and international trends and competition (strategic thinking). This dilemma directly represents the third dilemma discussed in the theory.
The literature outlines this task as one of the most significant roles of the board (Institute of Directors, 1995; Dimma, 1995; Garratt, 1996; Spira, 2001; Cornell, 2003 and Taylor, 2003). Percy (1995) clearly places an emphasis on the conflict between daily short-term management of the business and strategic thinking, thus confirming its stature as a dilemma. Manifestations of the third core corporate governance dilemma are presented in Table 8.

Table 8

Manifestations of core corporate governance dilemma three

\begin{tabular}{|l|l|}
\hline \multicolumn{1}{|c|}{ Short-term local demands } & \multicolumn{1}{|c|}{ Broader long-term trends and competition } \\
\hline $\begin{array}{l}\text { Organisational efficiency in the form of short-term } \\
\text { internal supervision and control of management. }\end{array}$ & $\begin{array}{l}\text { Organisational effectiveness in the form of long-term } \\
\text { strategic thinking (resource allocation and processes to } \\
\text { implement strategy) respectively. }\end{array}$ \\
\hline $\begin{array}{l}\text { Maintaining short-term earnings targets and smooth } \\
\text { earnings. }\end{array}$ & $\begin{array}{l}\text { Long-term sustainability and setting of corporate } \\
\text { direction of the business. }\end{array}$ \\
\hline
\end{tabular}


Core corporate governance dilemma four The fourth core corporate governance dilemma identified in the study was:

The board is required to focus on the commercial needs of business whilst operating responsibly to all stakeholders in society (customers, suppliers and society) and in the business (employees and business partners). This dilemma is the fourth dilemma discussed in the literature review. Four of the 12 dilemmas identified in the first two rounds of the study were consolidated into this core corporate governance dilemma. These are illustrated in Table 9.

The literature provides mention of the balance required between maintaining a focus on the commercial needs of the business and operating fairly and responsibly to all stakeholders (Garratt, 1996; King Committee on Corporate Governance, 2002; Coyle, 2003 and Smith, 2003).

\section{Table 9}

Manifestations of core corporate governance dilemma four

\begin{tabular}{|l|l|}
\hline \multicolumn{1}{|c|}{ Commercial needs (for shareholders) } & \multicolumn{1}{c|}{ Responsibility to all stakeholders } \\
\hline Prudent cost control. & $\begin{array}{l}\text { Attractive remuneration for directors to acquire and } \\
\text { retain talent. }\end{array}$ \\
\hline Being focused on the commercial needs of the business. & Addressing social charter and BEE priorities. \\
\hline $\begin{array}{l}\text { Keeping executive remuneration at national levels to } \\
\text { satisfy the media, investors and shareholders. }\end{array}$ & $\begin{array}{l}\text { Setting executive remuneration at international levels } \\
\text { to retain talent. }\end{array}$ \\
\hline Maintaining established competence. & $\begin{array}{l}\text { Providing careers for previously disadvantaged } \\
\text { employees (employment equity). }\end{array}$ \\
\hline Economic goals. & \begin{tabular}{l} 
Social goals. \\
\hline Economic goals.
\end{tabular} \\
\hline $\begin{array}{l}\text { Managing the potential impact of HIVIAIDS in the } \\
\text { workplace. }\end{array}$ \\
\hline
\end{tabular}

This issue is pertinent to directors in South Africa for the very reasons pointed out by the King Committee on Corporate Governance (2002:114) as it states, "Increasingly, South African companies are seen as agents of change not only for their own benefit but also for the benefit of their stakeholders."

\section{Core corporate governance dilemma five}

The fifth core corporate governance dilemma identified in the Delphi study was: The board is tasked with holding a balance between addressing board succession for diversity, complimentary skills and independence and keeping the current set of very competent and successful directors. The literature makes no mention of this dilemma and thus this is a new finding, regarding corporate governance dilemmas facing boards. The manifestations of this dilemma are illustrated in Table 10.

\section{Table 10}

Manifestations of core corporate governance dilemma five

\begin{tabular}{|l|l|}
\hline \multicolumn{1}{|c|}{ Diversity and complementary skills } & \multicolumn{1}{c|}{ Continuity } \\
\hline $\begin{array}{l}\text { Fostering independence and objectivity of the board, } \\
\text { which is important for international investors and } \\
\text { institutional credibility. }\end{array}$ & $\begin{array}{l}\text { Keeping competent and successful directors for } \\
\text { performance and continuity. }\end{array}$ \\
\hline $\begin{array}{l}\text { Blindly complying with King II in a small economy } \\
\text { lacking in diversity of experience and independence. }\end{array}$ & $\begin{array}{l}\text { Keeping competent and successful directors for } \\
\text { performance and risking a heavier workload, additional } \\
\text { risks and negative judgement by the market. }\end{array}$ \\
\hline
\end{tabular}


The findings capture the dynamics of the dilemma by mentioning how the extreme options of the dilemma affect each other in ways that imply conflicting gains. For example, maintaining continuity of superior human capital with skill and experience could contribute positively to performance. Blind compliance for diversity in a market lacking experience and independence will possibly lead to poor quality in terms of appointments that would possibly affect performance negatively.

\section{Core corporate governance dilemma six}

The sixth core corporate governance dilemma identified in the study was:

The board must hold a balance between incurring shareholder activism as a result of lower profit levels and incurring increased wage demands, calls for price reductions and complacency as a result of exceptionally high profit levels. The literature makes no mention of this dilemma. This is also a new finding, regarding corporate governance dilemmas facing boards. The manifestation of this dilemma was gleaned from the study and is illustrated in Table 11.

\section{Table 11}

Manifestations of core corporate governance dilemma six

\begin{tabular}{|l|l|}
\hline Shareholder activism and failure to source funding & $\begin{array}{c}\text { Increased wage demands, calls for price reductions } \\
\text { and complacency }\end{array}$ \\
\hline $\begin{array}{l}\text { Mitigating/protecting reputational risk in light of } \\
\text { shareholders. }\end{array}$ & $\begin{array}{l}\text { Mitigating/protecting reputational risk in light of all } \\
\text { other stakeholders. }\end{array}$ \\
\hline
\end{tabular}

\section{Rating of the core corporate governance dilemmas facing boards}

The section relates directly to the second research question and presents the results of the rating of the six core corporate governance in the third round of the Delphi study on an importance scale of 1 to 10 where 1 was of little concern and 10 was most prominent. The median of the ratings for each dilemma was calculated to indicate their relative importance. The medians are shown in Table 5. The rating of the dilemmas by the experts indicate that the dilemmas are all but equally important and hence can all be seen as core dilemmas facing boards.

\section{6}

\section{Limitations}

Delphi studies use small and purposive samples of experts and are not intended to be representative of the population. External validity could therefore not be verified but the sample was considered adequate for sound conclusions to be drawn. The results are cogent and plausible. The Delphi technique ensured internal validity by directing respondents to identify and rate the core corporate governance dilemmas facing boards themselves, thereby removing bias and ensuring that corporate governance dilemmas identified in the literature do indeed exist in practice. The scope of the study was limited to the corporate governance dilemmas, structures and processes of South African boards. The research focused on the role of the board and its directors in terms of activities only. The orientation was therefore on process and not on structure or law.

\section{7}

\section{Recommendations}

It is important to note that paradox and dilemmas can only be managed and not solved or resolved (Handy, 1995 and Rhinesmith, 2001). Handy (1995) believes that dilemmas should be managed by keeping the balance between both horns of the paradox and by empowering different people to manage each horn. Rhinesmith (2001) argues that different parties should manage the conflicting and contradictory situations by optimising and not by maximising their positions, and by having empathy for the other party's position. If diverse skills and people are used to manage different 
horns of a dilemma, people must trust, empower and have mutual confidence in their colleagues and take risks (Handy, 1995).

Richardson (1995) asserts that in order to manage paradox, leaders need to create organisations and systems that employ opposing approaches simultaneously and flexibly. Berry and Hülsmann (2004) also state that management configurations need to cope with opposing demands towards a system by maintaining an increasingly less consistent state, and by bearing greater tensions due to contradictions. They believe that in order to deal with the complexities of managing both horns of board dilemmas, a board system must deal with its own complexity whilst being open to the environment so as to absorb the complexities posed by its stakeholders. Handy (1995) argues that one way of making sense of and managing paradox is by maintaining a sense of continuity, having faith in the future and the colleagues one relies on and by taking the necessary risks to support sustainability of the company and the surrounding environments.

\section{Suggestions for further research}

This study was conducted on a purposive sample in South Africa and the core corporate governance dilemmas facing boards should be explored and statistically tested on a much larger sample and in other countries. A further study should focus on how the mix and relative importance of the six dilemmas identified changes by industry. An investigation should be carried out as to the competencies required by board members to cope with the dilemmas and paradoxes.

\section{Conclusion}

Since the literature was sparse on the corporate governance dilemmas facing boards, the findings of this research provide valuable insights into establishing what these dilemmas are. The research findings therefore also provide value by highlighting the nature of the conflicting requirements placed on them. This information should equip boards to identify which dilemmas are most pertinent to their directors and thus to begin a process of managing the conflicting pressures they face.

\section{8}

\section{References}

\section{AFRICAN INSTITUTE OF CORPORATE}

CITIZENSHIP, 2002. Socially responsible investment in

South Africa, Johannesburg: The AICC.

BERRY, A. \& HÜLSMANN, M., 2004. Strategic

management dilemma: its necessity in a world of diversity and change, SAM/IFSAM VII World Congress,

Göteborg, 5-7 July, Proceedings of the SAM/IFSAM

VIIth World Congress on Management in a World of Diversity and Change: 1-43.

CARDNO, C., 1998. Making a difference by managing dilemmas, Set Research Information for Teachers, 13(1): 1-4.

CARTER, C.B. \& LORSCH, J.W., 2003. Back to the drawing board, (1st ed). Boston: Harvard Business School Press.

CESCON, F., 2002. Short-term perceptions, corporate governance and the management of R \& D in Italian companies, Journal of Management and Governance, 6(3): 255-270.

CLAYTON, M.J., 1997. Delphi: a technique to harness expert opinion for critical decision-making tasks in education, Educational Psychology, 17(4): 373-386. CORNELL, B., 2003. The information that boards really need, MIT Sloan Management Review, 44(3): 71-76.

COX, J.D., 2003. Reforming the culture of financial reporting: The PCAOB and the metrics for accounting measurements, Washington University Law Quarterly, 81(301), 301-327.

COYLE, B., 2003. Corporate Governance, (1st ed). London: ICSA Publishing Ltd.

DIMMA, W.A., 1995. The Changing Role of the Board of Directors, Conference sponsored by The Institute of Corporate Directors and The Planning Forum, Toronto, 11 October, 217-220.

ERFFMEYER, R.C., ERFFMEYER, S.E. \& LANE, I.M., 1986. The Delphi technique: an empirical evaluation of the optimal number of rounds, Group \& Organisation Studies, 11(1-2): 120-128.

FREEMAN, R.E. \& HARRISON, J.S., 1999. Stakeholders, social responsibility, and performance: empirical evidence and theoretical perspectives, Academy of Management Journal, 42(5): 479-485. GARRATT, B., 1996. The fish rots from the head, (1st ed). Hammersmith: HarperCollins Publishers. GARRATT, B., 2003. Thin on top, (1st ed). London: Nicholas Brealey Publishing.

GEORGE, B., 2003. Managing stakeholders vs. responding to stakeholders, Strategy and Leadership, 31(6): 36-40. 
GRAHAM, J.R., HARVEY, C.R. \& RAJGOPAL, S., 2004. The economic implications of corporate financial reporting, NBER Working Paper, w10550, 1-42. HAMPDEN-TURNER, C., 2003. Strategic dilemmas occasioned by using alternative scenarios of the future, in Developing strategic thought, a collection of the best thinking on business strategy, B Garratt (Ed). ( $2^{\text {nd }}$ ed). London: Profile Books Ltd: 119-168.

HANDY, C., 1995. The empty raincoat, (1st ed). London: Random House Business Books. HARTSLIEF, M.A., 2003. The structure and function of the board of directors, Unpublished MBA Project Report, Johannesburg: University of the Witwatersrand.

HEMPHILL, T.A., 1996. Enterprise strategy and corporate environmental alliance, Business Forum, 21(1-2): 8-12.

HESS, D., 2001. Regulating corporate social performance: a new look at social accounting, auditing, and reporting, Business Ethics Quarterly, 11(2): 307330 .

HIGGS, D., 2003. Review of the role and effectiveness of non-executive directors, London: The Department of Trade and Industry.

INSTITUTE OF DIRECTORS, 1995. Standards for the board, (rev ed). London: Institute of Directors. KEAY, M., 2002. Towards global corporate social responsibility, The Royal Institute of International Affairs Sustainable Development Programme, Chatham House, April, Briefing Paper No. 3: 1-8. KING, A.M., 1992. Financial statements: revealing profits GAAP may conceal, Business Credit, 94(9): 10-11. KING COMMITTEE ON CORPORATE GOVERNANCE, 1994. The King Report on Corporate Governance, South Africa: The Institute of Directors in Southern Africa.

\section{KING COMMITTEE ON CORPORATE}

GOVERNANCE, 2002. The King Report on Corporate Governance for South Africa 2002: The Institute of Directors in Southern Africa.

KPMG, 2001. Research and survey report on environmental accounting in South Africa, Research Report, Cape Town: KPMG Inc. South Africa. LIVNE, G. \& McNICHOLS, M., 2004. An empirical investigation of the true and fair override, Journal of Accounting Research Conference on Financial Reporting and Capital Markets, Chicago, 7-8 May: 1-52. LOO, R., 2002. The Delphi method: A powerful tool for strategic management, Policing: An International Journal of Police Strategies \& Management, 25(4): $762-$ 769.

MARKS, S.G., 1999. The separation of ownership and control, Encyclopedia of law and economics, 5630: 692-724.
MILES, M.B. \& HUBERMAN, A.M., 1994.

Qualitative data analysis, (2 $\left.2^{\text {nd }} \mathrm{ed}\right)$. Thousand Oaks: Sage Publications, Inc.

MINKES, A.L., SMALL, M.W. \& CHATTERJEE, S.R., 1999. Leadership and business ethics: does it matter? Implications for management, Journal of Business Ethics, 20(4): 327-335.

MYBURGH, J.F., 2003. The Myburgh Report on the standard of corporate governance in the five largest banks, Johannesburg: South African Reserve Bank. PERCY, J.P., 1995. The Cadbury report and corporate governance in the UK, The CPA Journal, 65(5): 24-28. RHINESMITH, S.H., 2001. How can you manage global paradox?, The Journal of Corporate Accounting \& Finance, 12(6): 3-9.

RICHARDSON, B., 1995. Paradox management for crisis avoidance, Management Decision, 33(1): 5-18. SCHERRER, P.S., 2003. Directors' responsibilities and participation in the strategic decision making process, Corporate Governance, 3(1): 86-90.

SENGE, P., 1990. The fifth discipline: the art and practice of the learning organisation, New York:

Doubleday Currency.

SHARMAN, R. \& COPNELL, T., 2003. Performance from conformance: the practical application of corporate governance and risk management, Akauntan Nasional, 16(4): 20-23.

SHENG, A., 2003. Opening address by the chairman of the securities and futures commission Hong Kong, The enterprise governance forum 2003, Hong Kong, 26 November: 1-4.

SILLANPÄÄ, M., 1998. The body shop values report - Towards integrated stakeholder auditing, Journal of Business Ethics, 17(13): 1443-1456.

SMITH, NC, 2003. Corporate social responsibility: whether or how?, California Management Review, 45(4): 52-76.

SPIRA, L.F., 2001. Enterprise and accountability: striking a balance, Management Decision, 39(9): 739748.

STORY, V., HURDLEY, L., SMITH, G. \& SAKER, J., 2001. Methodological and practical implications of the Delphi technique in marketing decision-making: a re-assessment, The Marketing Review, 1(4): 487-504. SUNDARAMURTHY, C. \& LEWIS, M., 2003. Control and collaboration: paradoxes of governance, Academy of Management Review, 28(3): 397-415. TAYLOR, B., 2003. Board leadership: balancing entrepreneurship and strategy with accountability and control, Corporate Governance, 3(2): 3-5.

TRICKER, R.I., 1984. Corporate governance, (1st ed). Vermont: Gower Publishing Company Limited. UNIVERSITY OF CAMBRIDGE, 2002. Sustainability and profitability: conflict or convergence? 
The $6^{\text {th }}$ Senior Executives' Seminar, Salzburg, 23-27 September, 1-16.

WIXLEY, T. \& EVERINGHAM G., 2002. What you must know about corporate governance, (1st ed). Claremont: Siber Ink CC.

ZAHRA, S.A., 1996. Governance, ownership, and corporate entrepreneurship: the moderating impact of industry technological opportunities, Academy of Management Journal, 39(6): 1713-1735.

ZAHRA, S.A., NEUBAUM, D.O. \& HUSE, M., 2000. Entrepreneurship in medium-size companies: exploring the effects of ownership and governance systems, Journal of Management, 26(5): 947-976.

ZIKMUND, W.G., 2003. Business research methods. Thomson: South Western Ohio. 